\title{
A (IM)POTÊNCIA DA EXPERIÊNCIA E DO INDIVÍDUO EM FIM DE PARTIDA*
}

\author{
Yonara Dantas de Oliveira \\ Fundação Getúlio Vargas, São Paulo, São Paulo, Brasil
}

\begin{abstract}
REsUmo: Este ensaio revisita os conceitos de experiência e indivíduo em Adorno, Horkheimer e Benjamin, no que os autores revelam sobre o caráter fragmentário e impotente com que esses conceitos se apresentam na modernidade. Parte-se de tais considerações para refletir acerca da peça Fim de partida, de Samuel Beckett, que se mostra, particularmente para Adorno, como denúncia realista das condições deterioradas de formação do indivíduo. É por meio da forma de paródia do drama que Beckett expõe a dilaceração das possibilidades de contato entre os homens e desses com a natureza e o mundo. A (im)potência da experiência e do indivíduo é o preço a ser pago pela humanidade, que segue seu curso no progresso à custa da morte em vida de todos.
\end{abstract}

Palavras-chave: Experiência. Indivíduo. Escola de Frankfurt. Teatro moderno.

\section{NOTAS INTRODUTÓRIAS}

A humanidade teria alcançado as condições objetivas para a constituição de cada homem como indivíduo, no momento em que a condição social deixa de ser imediatamente dada e cada homem se torna, em potencial, capaz de referendar uma condição social por meio do trabalho, como se observa na transformação social que leva do feudalismo medieval ao período burguês. “[...] não é mero acidente fortuito que só por volta do século XVIII a palavra'indivíduo' tenha passado a designar o homem singular, e que a própria coisa não seja muito mais antiga que a palavra, dado que só começou a existir nos alvores do renascimento" (HORKHEIMER; ADORNO, 1973, p. 52).

\footnotetext{
* Artigo recebido em 17/05/2013 e aprovado em 15/8/2013.
} 
Todavia, alcançar condições objetivas de transformação social não torna qualquer homem um indivíduo; o indivíduo não é um a priori. Ele se constitui nas suas experiências com o mundo e com os outros - com os quais se identifica e por meio das quais se diferencia -, o que fomenta a autorreflexão que subsidia a individuação. Quanto mais ricas essas experiências, mais se fortalece como indivíduo. $\mathrm{O}$ homem depende de experiências, mas o que se observa, em especial a partir das considerações de Benjamin, é que a experiência mesma se encontra em crise.

O indivíduo burguês se encontra oprimido pela oposição entre a existência burguês-particular e a político-universal. Para o indivíduo que deve lutar, de modo implacável, por seus interesses de lucro sem se preocupar com o bem da coletividade, a realidade converte-se em aparência, e a aparência, em realidade. A sociedade burguesa está dominada pelo equivalente e isso faz com que prevaleça a tendência a tornar o heterogêneo comparável, reduzindo-o a grandezas abstratas. Como consequência, afirmam Horkheimer e Adorno (1985, p. 23): "Para o esclarecimento, aquilo que não se reduz a números e, por fim, ao uno passa a ser ilusão: o positivismo moderno remete-o para a literatura. [...] O que se continua a exigir insistentemente é a destruição dos deuses e das qualidades".

O ideal antifeudal da autonomia na decisão política dos indivíduos, no contexto econômico, transformou-se em uma ideologia que exige a manutenção da ordem e a intensificação da capacidade de realização produtiva. Com isso,

O indivíduo vê-se completamente anulado em face dos poderes econômicos. Ao mesmo tempo, esses elevam o poder da sociedade sobre a natureza a um nível jamais imaginado. Desaparecendo diante do aparelho a que serve, o indivíduo vê-se, ao mesmo tempo, melhor do que nunca provido por ele. Numa situação injusta, a impotência e a dirigibilidade da massa aumentam com a quantidade de bens a ela destinados. A elevação do padrão de vida das classes inferiores, materialmente considerável e socialmente lastimável, reflete-se na difusão hipócrita do espírito. Sua verdadeira aspiração é a negação da reificação. Mas ele necessariamente se esvai quando se vê concretizado em um bem cultural e distribuído para fins de consumo. A enxurrada de informações precisas e diversões assépticas desperta e idiotiza as pessoas ao mesmo tempo. (HORKHEIMER; ADORNO, 1985, p. 14)

O aumento da produtividade econômica oferece condições para um mundo mais justo, mas também depaupera a cultura. $O$ esclarecimento precisa tomar consciência de si, a fim de que não frustre seu próprio potencial emancipatório. O prognóstico desses autores sobre a conversão do 
esclarecimento no mito dos fatos e, finalmente, na identidade da inteligência e na hostilidade ao espírito reiteram seu argumento acerca da mitologização no desenvolvimento da razão, que metamorfoseia o medo do desconhecido em falsa autoridade sobre o mundo - homens predadores dos outros e da natureza.

A seguinte citação de Theodor W. Adorno coloca em evidência os aspectos concernentes à experiência e ao indivíduo, impressos na peça Fim de partida, de Samuel Beckett, a qual buscamos pormenorizar neste ensaio:

As catástrofes que inspiram Fim de partida fazem saltar pelos ares aquele indivíduo cuja substancialidade e condição absoluta constituía o que de comum havia em Kierkegaard, Jaspers e a versão sartreana do existencialismo. Esta havia, inclusive, certificado às vítimas dos campos de concentração a liberdade de aceitar ou negar interiormente o martírio infligido. Fim de partida destrói esse tipo de ilusão. $\mathrm{O}$ indivíduo mesmo, enquanto categoria histórica, resultado do processo capitalista de alienação e desafiante protesto contra esse, se configura uma vez mais patente como algo efêmero. A postura individualista se situa no pólo oposto ao princípio existencial de todo existencialismo, incluindo o do Ser e tempo. A dramaturgia de Beckett o abandona como a um refúgio antiquado. Em sua estreiteza e contingência, a experiência individual não recebeu de nenhuma parte a autoridade para interpretar-se a si mesma como cifra do ser, a não ser que afirme a si mesma como caráter fundamental do ser. Mas isso precisamente é falso. A imediatidade da individuação era um engano. O que concerne à experiência humana individual é mediado, condicionado. (ADORNO, 2003, p. 279-280; grifo nosso)

Das várias questões condensadas nessa citação, destacamos o modo como a possibilidade de formação do indivíduo depende da história que, em essência, o constitui. A simples negação da realidade opressiva - como propõe Sartre, em favor de uma abstração falsamente libertária e desconectada do real - faz um desserviço aos homens; na destilação do que lhe parece atemporal no particular, perde exatamente o que faz do homem um indivíduo: um ser individuado no tempo e no espaço. O gesto de recusa se encontra impresso em obras como a peça Fim de partida, na medida em que não disfarça, mas representa e desdobra a possível condição da humanidade depois dos campos de concentração.

Neste ensaio, abordamos a problemática envolvendo a experiência - empobrecida frente ao desenvolvimento técnico e instrumentalizado da razão - e seus desdobramentos na constituição do indivíduo; isso analisado sob o ponto de vista da reificação da vida em meio à indiferenciação entre homens e coisas, da qual sobrevive a sociedade de trocas. Também avaliamos 
suas consequências funestas na representação de um drama sem vida, tal como se observa em Fim de partida.

\section{PARTE I}

Benjamin (1995, p. 195-196) é categórico ao afirmar que "uma miséria totalmente nova se abateu sobre o homem com esse desenvolvimento monstruoso da técnica. [...] Pois qual o valor de todo o nosso patrimônio cultural, se a experiência não o vincula a nós?". Um prognóstico similar é apontado por Adorno (2008, p. 56): “[...] o cerne da experiência encontra-se esgotado; nenhuma experiência, nem sequer a que se subtrai imediatamente ao comércio, deixou de ser minada".

A possibilidade de passar por experiências e ainda de comunicálas, como algo que faz sentido e pode fazer diferença na determinação objetiva dos rumos de uma vida, tem sido proscrita. Não há discurso capaz de sedimentar as potencialidades de realização de uma vida digna e torná-la transmissível frente ao rápido desenvolvimento tecnológico e as constantes adaptações requeridas. A experiência incomunicável torna-se vivência. $E$, como destacam Horkheimer e Adorno (1985, p. 47), “Quanto mais complicada e mais refinada a aparelhagem social, econômica e científica, para cujo manejo o corpo já há muito foi ajustado pelo sistema de produção, tanto mais empobrecidas as vivências de que ele é capaz".

As narrativas eram redutos da experiência. Seu pressuposto era uma comunidade de ouvintes e um sentido comum de existência. Seu discurso, permeado pelas impressões daquele que narrava, alcançava o universal por meio de um mergulho na particularidade do narrador. A história narrada apresentava um viés prático, configurava-se como uma espécie de conselho, tal como se observa no exemplo de narrativa ancorada na experiência, oferecido por Benjamin:

Em nossos livros de leitura havia a parábola de um velho que, em seu leito de morte, revela a seus filhos a existência de um tesouro escondido em sua vinha. Eles só precisariam cavar. E cavaram, mas nem sombra do tesouro. Com a chegada do outono, porém, a vinha produz como nenhuma outra em toda a região. Só então eles percebem que o pai havia lhes legado uma experiência: a benção não se esconde no ouro, mas no trabalho. Experiências como essas nos foram transmitidas de modo benevolente ou ameaçador, enquanto crescíamos: "Esse menino pensa que é gente, já quer dar palpite"; ou: "Você ainda tem muito para aprender". Sabia-se muito bem o que era a experiência: as pessoas mais velhas sempre a passavam aos mais jovens. (BENJAMIN, 1995, p. 195) 
De forma concisa, atrelada à autoridade dos mais velhos; de modo prolixo, em histórias; ou, mesmo, como narrativas distantes, contadas em família no aconchego do lar - assim, as experiências eram apresentadas entre gerações e ofereciam conhecimentos válidos aos ouvintes. Mas já no início do século XX, Benjamin questionava:

Para onde foi tudo isso? Quem ainda encontra pessoas que saibam contar histórias como devem ser contadas? Por acaso os moribundos de hoje ainda dizem palavras tão duráveis que possam ser transmitidas de geração em geração como se fossem um anel? A quem ajuda, hoje em dia, um provérbio? Quem sequer tentará lidar com a juventude invocando sua experiência? (BENJAMIN, 1995, p. 195)

A rapidez das mudanças - ocorridas com a expansão do capitalismo e necessidade de exposição e circulação ágil de mercadorias - se contrapõe à comunicação entre as gerações. O ritmo do tempo na vida moderna exige adaptações ao corpo e ao pensamento. Os processos cíclicos da natureza e o processo orgânico de trabalho da era pré-capitalista ganharam contornos fragmentários, rotineiros e mecânicos. A necessária e instável busca pela sobrevivência, em uma sociedade calcada no efêmero e no vazio, propõe estimulação constante na consciência - choques que nos atingem, mas não deixam reminiscências. Como afirma Crochík (2010), a subjetividade característica do século XIX, e introjetada no século XX, é a traumática, aquela que produz ansiedade constante como forma de defesa aos estímulos que geram traumas psíquicos.

Em contrapartida, a tessitura da experiência se fundamenta em pressupostos diferentes: "O tédio é o pássaro de sonho que choca os ovos da experiência. $O$ menor sussurro nas folhagens o assusta. Seus ninhos, as atividades intimamente associadas ao tédio já se extinguiram nas grandes cidades e estão em vias de extinção no campo" (BENJAMIN, 1996, p. 204205). A perda da experiência faz parte de um longo processo que começa com o desenvolvimento da produção nas manufaturas e atinge seu ápice na indústria. Transformado em autômato pela exigência da maquinaria com a qual precisa lidar, esse homem adquire uma nova sensibilidade, danificada, que renega o natural em nome de uma pretensa autoridade sobre o mundo.

Para Benjamin (1995), o resultado da pobreza da experiência é uma nova espécie de barbárie, que impele o homem a seguir em frente, a começar de novo, a contentar-se com pouco, a construir com pouco, sem olhar para os lados. Uma tendência progressiva e arbitrária que contrasta com a dimensão orgânica da vida. Em meio a essa tábula rasa, pobre em vivências, não se deve imaginar que os homens aspirem a novos experimentos: "Não, eles aspiram 
a libertar-se de toda experiência, aspiram a um mundo em que possam fazer valer tão pura e claramente a sua pobreza, externa e interna, que disso resulte algo decente" (BENJAMIN, 1995, p. 197-198).

Ainda com Benjamin, observamos que nem sempre se trata de ignorância; podemos afirmar o oposto: no "bombardeio" de informações, eles "devoram" tudo, a "cultura" e os "homens", e ficam saciados e exaustos tendo como mote a constante inovação que requer desapego. A natureza e a técnica, o primitivismo e o conforto se unificam por completo e, aos olhos das pessoas, fatigadas, surge uma existência que se basta a si mesma, necessariamente indiferenciada.

As implicações da crise da experiência, da fragmentária e indiferenciada vida moderna, na constituição de cada homem em particular, são apresentadas por Horkheimer e Adorno (1985) na análise que os autores realizam como fechamento de suas reflexões no livro Dialética do esclarecimento. Do último texto da parte "Notas e esboços", sobre a gênese da burrice, destacase uma metáfora sobre a inteligência e a sensibilidade. Segundo os autores:

O símbolo da inteligência é a antena do caracol "com a visão tateante", graças à qual, a acreditar em Mefistófeles, ele é também capaz de cheirar. Diante de um obstáculo, a antena é imediatamente retirada para o abrigo protetor do corpo, ela se identifica de novo com o todo e só muito hesitantemente ousará sair de novo como um órgão independente. Se o perigo ainda estiver presente, ela desaparecerá de novo, e a distância até a repetição da tentativa aumentará. Em seus começos, a vida intelectual é infinitamente delicada. O sentido do caracol depende do músculo, e os músculos ficam frouxos quando se prejudica seu funcionamento. $O$ corpo é paralisado pelo ferimento físico, o espírito pelo medo. Na origem, as duas coisas são inseparáveis. (HORKHEIMER; ADORNO, 1985, p. 239)

No contato com o mundo externo, o qual possibilita a experiência que permite o desenvolvimento do corpo e do espírito, a inteligência e o pensamento se constituem. Caso o contato seja agressivo ou ameaçador, esse tatear necessário ao aprendizado pode ficar comprometido, resultando na inibição do jogo dos músculos em suas primeiras tentativas. Frente a uma violenta resposta do ambiente exterior, o órgão sensível se atrofia, fomentando timidez e burrice. $O$ órgão afugentado, medroso, se torna menos sensível como a pele em que residem cicatrizes; pequenos enrijecimentos podem tornar as pessoas insensíveis e, consequentemente, burras. Esse entrelaçamento obstado entre sensibilidade e pensamento se revela"no sentido de uma manifestação de deficiência, da cegueira e da impotência, quando ficam estagnadas, no sentido da maldade, da teimosia e do fanatismo, quando desenvolvem um câncer interior" (HORKHEIMER; ADORNO, 1985, p. 240). 
O ritmo frenético das grandes cidades e o consumo compulsivo, há muito, perderam de vista o atendimento de necessidades, não deixam espaço para o pensamento. A indiferenciação entre os objetos reflete a impossibilidade de discernimento da qual sobrevive o mercado.

Do ponto de vista da coletividade, deve-se avaliar se a sociedade permite ao indivíduo ser tão livre quanto lhe promete e, com isso, se a própria sociedade o é. A sociedade determina os indivíduos naquilo que eles podem ser; a liberdade não é dada a priori. "O principium individuations [...] não é de maneira alguma o elemento derradeiro e imutável, e, por isso, também não o é a liberdade" (ADORNO, 2009, p. 185). A liberdade é um fator em um duplo sentido: "não é isolável, mas acha-se entretecida; e por enquanto ela não passa de um instante de espontaneidade, de um ponto nodal histórico, encoberto pelas condições atuais" (p. 185). Alguma repressão da natureza é fundamental para a consolidação da civilização, mas ela deveria ser corroborada pela liberdade. Sem condições de realizá-la, a repressão se converte em mais-repressão (termo de Herbert Marcuse), em que a liberdade é ainda uma promessa não cumprida.

\section{PARTE II}

O processo de enfraquecimento da experiência se apresenta como pano de fundo para o enfraquecimento do "eu". O indivíduo seria aquele capaz de oferecer e vivenciar experiências verdadeiras, dignas de serem comunicadas, que confeririam, juntamente com a tradição, a referência histórica da vida vivida. Mas, imersos no individualismo e em uma fragmentada experiência, nos encontramos alijados uns dos outros.

As condições mesmas de constituição do indivíduo, potencializadas pela sociedade burguesa, fomentaram, também, o individualismo que acaba por negá-lo. A separação empreendida pelo Estado burguês entre o homem e o cidadão redefiniu as esferas do privado e do público, o que resultou na despolitização da vida doméstica, no fechamento do indivíduo em si mesmo e na família. No interior do lar, o burguês mantém a ilusão de um universo harmonioso e trata de esquecer as contradições da sociedade. "A fantasmagoria da cultura capitalista se desdobra no interior burguês: cortinas, papéis de parede, quadros, molduras rebuscadas, tapetes etc. devem montar um cenário capaz de oferecer segurança e apoio espiritual aos personagens. Além do conforto, é preciso solidez e beleza, em oposição à fragilidade e à feiura do mundo do lado de fora" (D'ANGELO, 2006, p. 60).

A noção do indivíduo como mônada, de Leibniz, ofereceu o modelo conceitual para a visão individualista do homem na sociedade burguesa:"'as 
mônades não têm janelas pelas quais possam entrar ou sair alguma 'coisa' e as modificações que nelas ocorrem não têm causas externas, mas derivam, outrossim, de um 'princípio interno'. Por último, cada mônade é diferente das outras todas" (LEIBNIZ apud HORKHEIMER; ADORNO, 1973, p. 46-47).

As contribuições da sociologia mostraram, em contrapartida, que o indivíduo mesmo é socialmente mediado. O homem é, por natureza, convivência; o indivíduo não se configura como ser isolado:

Se o homem, na base de sua própria existência, é para os outros, que são os seus semelhantes, e se unicamente por eles é o que é, então a sua definição última não é a de uma indivisibilidade e unicidade primárias, mas, outrossim, a de uma participação e comunicação necessárias com os outros. (HORKHEIMER; ADORNO, 1973, p. 47)

O homem é um dos seus semelhantes, e essa etapa de identificação é fundamental para a autodeterminação. Todavia, no momento histórico em que alcançamos elevado nível de desenvolvimento técnico, capaz de oferecer condições básicas de subsistência a todos, estamos imersos em um individualismo no qual, esquecidos uns dos outros, não há ocasião para o diálogo. A anulação do outro se volta como anulação de si mesmo. 0 indivíduo, interiorizado em si mesmo, se torna simulacro.

Na sociedade de trocas amplamente desenvolvida e "democrática", a angústia decorrente da desproporção entre o poder das instituições e a impotência do indivíduo se generaliza. Nesse contexto, as possibilidades de liberdade e decisão de cada um se revelam tão frágeis que tem sido difícil aos homens pensar para além da heteronomia instalada.

A humanidade classificada como clientela, o sujeito das necessidades, está pré-formada socialmente mais além de toda representação ingênua, e isso não apenas pelo estado técnico das forças produtivas, senão também pelas relações econômicas, por mais difícil que isso resulte de controlar empiricamente. [...] Na redução dos homens a agentes e suportes do intercâmbio de mercadorias se oculta a dominação dos homens sobre os homens. (ADORNO, 2004, p. 13)

A intensificação da capacidade produtiva gira em falso, na medida que não possibilita uma vida digna de ser vivida aos homens como um todo. O caráter abstrato da taxa de câmbio conflui para o domínio do geral sobre o particular.

Nos dias atuais, a questão da liberdade possível é fundamental para a ciência psicológica, a fim de que não atue de maneira afirmativa: reiterando uma falsa liberdade individual em meio à não liberdade do todo; creditando, 
apenas, a cada homem as agruras de sua existência; e inviabilizando, com isso, a superação desse estado de coisas. A autoconsciência não se configura em um pensar dobrado sobre si mesmo:

Quanto mais, no criticismo, o eu mergulhava na contemplação do eu, tanto mais magro, sempre mais magro, ficava esse eu, até que acabou tornandose um fantasma, imortal como o marido de Aurora. Aconteceu com o eu o mesmo que com o corvo que, encantado com os elogios da raposa sobre sua pessoa, deixou cair o queijo. Enquanto a reflexão refletia constantemente sobre a reflexão, o pensamento se desencaminhou, e cada passo que ele dava adiante o afastava mais e mais de todo conteúdo. (KIERKEGAARD apud ADORNO, 2010, p. 72-73)

Ensimesmado, o eu se fragiliza. Diferentemente da noção determinista de identidade $E u=E u$, que deriva da noção matemática $A=A$, o indivíduo está em devir, e, portanto, não está concluído para contemplação; é algo em devir que depende da imbricada relação entre possibilidade e necessidade:

A personalidade é uma síntese de possibilidade e necessidade. Sua persistência se assemelha assim à respiração, é um inspirar e expirar. O eu mesmo (selbst) do determinista não pode respirar, pois é impossível respirar somente o necessário, o qual não faria senão asfixiar o homem. (KIERKEGAARD apud ADORNO, 2010, p. 222)

Nesse entrelaçamento entre o que se é (necessidade) e o que se pode ser (possibilidade), o indivíduo não conhece a si mesmo, mas escolhe a si mesmo. Então, toma consciência de si, e, nesse sentido, a autoconsciência não é uma contemplação, mas um ato mediado por condições históricosociais específicas.

Reitera-se, portanto, a importância do que é contingente a cada indivíduo, o que o torna um exemplar e um agente da história:"poderia muito bem ser que essas duas coisas permanecessem recusadas aos animais. Como é em si mesma universal, e porquanto o seja, a experiência individual também alcança o universal" (ADORNO, 2009, p. 47). É por meio da autorreflexão que a consciência individual, munida de suas experiências, consegue afirmar-se enquanto indivíduo. $\mathrm{E}$ o indivíduo oferece um contraponto necessário ao social:"se o indivíduo fosse cortado, não surgiria daí nenhum sujeito superior, purificado do entulho da contingência, mas unicamente um sujeito que seguiria um padrão de realização sem consciência" (p. 47).

A potência do indivíduo e da experiência reside, portanto, na possibilidade de desvelar a precisa correlação entre o particular e o todo - correlação da qual depende a própria possibilidade de constituição do 
humano. Essa se encontra impressa na noção de desenvolvimento do drama e se vê esfacelada no teatro moderno, devido à solidão e isolamento dos indivíduos entre si e, mesmo, frente à autoalienação de cada homem consigo mesmo.

PARTE III

Os personagens de Fim de partida encontram-se física e subjetivamente deteriorados. Do ponto de vista físico, temos Nagg e Nell, pais de Hamm, que perderam as pernas em um acidente e agora vivem/jazem em latões; Hamm, personagem central (inclusive por sua posição em cena), paralítico e cego; e Clov (criado/filho adotivo de Hamm) que mal pode ver e é coxo. Do ponto de vista subjetivo, personagens que se relacionam entre si de maneira agressiva, que observam a deterioração do mundo e de si e à qual não conseguem se opor:

Clov (Triste): Ninguém nunca pensou de modo tão tortuoso como nós.

Hamm: A gente faz o que pode.

Clov: Fazemos mal. (Pausa). (BECKETT, 2010, p. 49)

A peça se inicia com Clov observando o que há fora do abrigo por meio de uma luneta, através das janelas. $O$ abrigo possui janelas altas, que dependem de uma escada para que se possa alcançá-las. Depois de observar por todas as janelas, Clov retira os lenços que repousam em cima dos objetos cênicos: por cima dos latões em que se encontram Nagg e Nell e, por último, retira um grande lençol de cima de Hamm. Apenas um último lenço, posicionado sobre o rosto de Hamm e manchado de sangue, se mantém será retirado pelo próprio Hamm.

A primeira fala da peça, realizada por Clov, revela o anseio pelo fim: "(olhar fixo, voz neutra) Acabou, está acabado, quase acabando, deve estar quase acabando (pausa)" (BECKETT, 2010, p. 38). Concluída sua fala, afirma que irá dirigir-se à sua cozinha, o espaço que lhe é reservado: "Vou para a minha cozinha, três metros, por três metros, por três metros, esperar até que ele apite. (pausa) É um bom tamanho. Vou me encostar na mesa e olhar para a parede, esperando que ele apite" (p. 38). Depois que Clov sai de cena, Hamm retira o último lenço e inicia a sua fala, individualista e também marcada pelo desejo do fim:

Minha... (Bocejos)... vez. (Pausa) De jogar. (Segura olenço aberto à sua frentena ponta dos dedos) Trapo velho! (Tira os óculos, enxuga os olhos, o rosto, limpa os óculos, recoloca-os, dobra o lenço com cuidado e coloca-o com delicadeza 
no bolso do peito do roupão. Limpa a garganta, junta a ponta dos dedos) Pode haver... (Boceja)... miséria mais... mais sublime que a minha? Sem dúvida. Naquele tempo. Mas e hoje? (Pausa) Meu pai? (Pausa) Minha mãe? (Pausa) Meu... cão? (Pausa) Ah, é claro que admito que sofram tanto quanto criaturas assim podem sofrer. Mas isso quer dizer que nosso sofrimento seja comparável? Sem dúvida. (Pausa) Não, tudo é a... (Bocejo)... bsoluto, (Com orgulho) quanto maior o homem, mais pleno. (Pausa. Melancólico) E mais vazio. (Funga) Clov! (Pausa) Não, estou sozinho. (Pausa) Que sonhos! Aquelas florestas! (Pausa) Chega, está na hora de isso acabar, no abrigo também. (Pausa) E mesmo assim eu ainda hesito... em ter um fim. É, é isso mesmo, está na hora disso acabar e mesmo assim eu ainda hesito em ter um... (Boceja)... fim. (Boceja) Meu Deus, que há comigo hoje, devia ir me deitar. (Apita. Entra Clov imediatamente. Para ao lado da cadeira) Você polui o ar! (Pausa) Apronte-me, vou me deitar. (BECKETT, 2010, p. 38-39)

Na fala inicial de Hamm, observa-se o isolamento, a não identificação, a impotência das palavras e das ideias. As florestas, a natureza, o anseio pelo fim, são facilmente contrapostos ao bocejo e a manutenção da fala. Nem mesmo Clov atende ao que Hamm propõe. À frase "Apronte-me, vou me deitar", Clov afirma: "Não posso ficar levantando e deitando você a cada cinco minutos, tenho o que fazer" (p. 39). O que há para fazer, no entanto, é seguir o curso da peça.

Sobre o que se tem em cena, destacamos a Apresentação feita por Andrade: "o cenário é cinzento, austero, batizado de abrigo, em que os quatro habitantes vivem como se fossem os últimos sobreviventes de uma humanidade devastada, últimos resquícios de uma natureza que se esgota" (ANDRADE apud BECKETT, 2010, p. 14). Diferentemente dos aconchegantes lares burgueses, que se contrapunham à miséria exterior, o interior dessa casa sem mobílias não oferece alento à catástrofe.

Em Fim de partida, como em outras de suas peças, Beckett questiona os pressupostos da representação teatral. Até a cortina do teatro, que marca o início de uma peça, é substituída pelos lenços que pousam em cima dos personagens, retirados por Clov, dos quais apenas um subsiste:

Hamm, logo em seguida, recolherá o último, esse sim, reformador. Trata-se de um trapo que lhe cobre o rosto e lhe represa as palavras. [...] Reduzida a tapabocas, a cortina revela a natureza do palco, pois, puxado o pano (ou trapo), o palco se assume como lugar da palavra. (VASCONCELLOS, 2009, p. 51-52)

Tampouco a palavra em cena é aquela do diálogo clássico, portavoz da vontade de sujeitos livres, cujo confronto engendrava o drama. Aqui 
a palavra se encontra conformada e reitera a submissão e a desigualdade entre os personagens:

Hamm: Não vou lhe dar mais nada para comer.

Clov: Então nós vamos morrer.

Hamm: Vou lhe dar apenas o suficiente para você não morrer. Você vai ter fome o tempo todo.

Clov: Então nós não vamos morrer. (BECKETT, 2010, p. 42)

Sobre a forma de representação adotada por Beckett, Adorno (2003) afirma que a peça Fim de partida seria uma espécie de paródia do drama, gênero típico do período burguês. Em contraposição à perspectiva dramática proposta por Diderot (2005), para quem a ação dramática deve progredir como uma massa que despenca do topo de um rochedo, de modo que sua velocidade aumenta à medida que cai, saltando os obstáculos que encontra, em Beckett, a ação cênica precisa resistir ao marasmo.

Por meio da adoção dos pressupostos da forma dramática e seu desencontro com o conteúdo colocado em cena, revela-se tanto a impossibilidade de seguir representando segundo o cânon dramático, como se desvela que os modos subjetivos de reação que subsidiavam sua lei formal não são algo isento e neutro, mas objetivamente colocado. Em Fim de partida, segundo Adorno:

As categorias dramáticas são em sua totalidade tratadas como o humor. São parodiadas todas. Mas não se faz delas objeto de escárnio. Enfaticamente, paródia significa a utilização de formas na época de sua impossibilidade. Demonstra essa impossibilidade e com isso modifica as formas. As três unidades aristotélicas [tempo, lugar e causalidade] se conservam, mas o drama perde a vida. Com a subjetividade de que Fim de partida é epílogo, se lhe subtrai o herói; da liberdade, não conhece mais que o reflexo impotente e ridículo de decisões vãs. (ADORNO, 2003, p. 292)

É no Renascimento, e sobretudo na França do século XVII, que a dramaturgia encontra uma atualização precisa como gênero "primário", o que exclui a mediação de um sujeito épico. Cada ação é representada como se fosse a primeira vez: "Impõe-se um rigoroso encadeamento causal, cada cena sendo a causa da próxima e essa sendo o efeito da anterior: o mecanismo dramático move-se sozinho, sem a presença de um mediador que o possa manter funcionando" (ROSENFELD, 1965, p. 18-19). O "motor" dramático é o diálogo, e os personagens apenas logram constituir-se na contraposição de vontades, no confronto e interpelação com outros personagens. Da possibilidade do diálogo depende a possibilidade do drama: 
A esfera do 'inter' [intersubjetivo] Ihe parecia o essencial de sua existência; liberdade e formação, vontade e decisão, o mais importante de suas determinações. O "lugar" onde ele alcançava sua realização dramática era o ato de decisão. Decidindo-se pelo mundo da comunidade, seu interior se manifestava e tornava-se presença dramática. (SZONDI, 2001, p. 29)

Mas as unidades de tempo, lugar e causalidade e o diálogo, como elementos engendrantes da ação, perdem sua força expressiva quando o homem a ser representado não encontra palavras capazes de dar sentido à sua existência; quando, na realidade social, o que se observa é um homem submetido a fins cada vez mais exteriores ao humano, referidos à mera acumulação do capital, sem perspectiva ou garantia das condições mínimas de existência. Em que as possibilidades de liberdade e decisão, diante de opções massificadas e pré-moldadas, são tão ínfimas que praticamente não se encontram subsídios para a diferenciação. "A sociedade que estimulou o desenvolvimento do indivíduo, desenvolve-se agora, ela própria, afastando de si o indivíduo, a quem destronou" (HORKHEIMER; ADORNO, 1973, p. 55).

Nesse contexto, as peças de Samuel Beckett se oferecem como um espelho em que ficam claras as ruínas do diálogo, do todo da forma e, em última análise, da existência humana. Pensamentos soltos são apresentados como frases, de tal modo que o enunciado se presta apenas à negatividade, à fala automatizada, à impossibilidade de se cumprir a forma dramática. O seu potencial crítico ressurge, uma vez que o "diálogo", ou melhor, a sua impossibilidade remonta ao modo como vêm se configurando as relações sociais.

Segundo Adorno (2003), as peças de Beckett chegam a instituir uma nova forma de realismo, que reconstrói, na linguagem, a fragilidade do indivíduo burguês frente ao progresso adquirido:

Todo o progresso reivindicado para além do ponto foi adquirido à custa da regressão pela assimilação com o passado e pela arbitrariedade de uma ordem autônoma. Nos últimos anos, achou-se prazer em censurar a Samuel Beckett a repetição das suas concepções; ele expôs-se a essa censura de uma maneira provocante. A sua consciência foi justamente tanto a da necessidade de continuação como a da sua impossibilidade. O gesto do estar-sem-fazer-nada no final de Godot, figura fundamental de toda a sua obra, reage precisamente a essa situação. Responde de um modo violento e categórico. A sua obra é a extrapolação do kaıpoc [kairós] negativo. A plenitude do instante perverte-se em repetição sem fim, convergindo com o nada. (ADORNO, 2008, p. 55) 
O progresso reivindicado para "além do ponto" refere-se àquele progresso que ganha sentido em si mesmo e desconsidera os homens, a quem deveria servir. No gênero dramático, o presente (tempo atual) é absoluto e prenhe (grávido) do futuro. Aqui, o tempo fragmentado se reduz a breves instantes (kairós) e se contrapõe ao tempo acumulado (cronos). Kairós se refere a um tempo importante, mas, em Fim de partida, apresenta-se como acentuação do kairós negativo - é impotente, lampejo que não imprime nenhuma novidade ao curso da peça. $O$ presente não difere do passado:

Clov: Há tantas coisas terríveis.

Hamm: Não, não, não há tantas assim. (Pausa) Clov.

Clov: Fale.

Hamm: Você não acha que isso durou o bastante?

Clov: Acho! (Pausa) O quê?

Hamm: Esse... essa... isso.

Clov: Sempre achei. (Pausa) Você não?

Hamm: (Abatido) Então é um dia como os outros. (BECKETT, 2010, p. 88)

O fim retorna ao início, a ação cênica aponta para o nada. O "progresso" do drama, que não pode contar com o diálogo para se desenvolver, é então pontuado pelas entradas e saídas de Clov, o gesto titubeante do único que pode movimentar-se, apesar de coxo:

Hamm: (Com angústia) Mas o que está acontecendo, o que está acontecendo? Clov: Alguma coisa segue seu curso.

(Pausa)

Hamm:Tudo bem, vá embora. (Recosta a cabeça contra a cadeira, permanece imóvel. Clov não se mexe, suspira profundamente. Hamm endireita-se) Pensei ter dito para você ir embora.

Clov: Estou tentando. (Vai até a porta, para) Desde que nasci.

(Pausa)

Hamm: Estamos progredindo. (BECKETT, 2010, p. 52)

Hamm, provedor desse abrigo, considera-se o senhor da situação e, no auge de sua prepotência, se arroga ser o único responsável pelo fim. "Todos aqueles que eu poderia ter ajudado. (Pausa) Ajudar! (Pausa) Salvar. (Pausa) Salvar! (Pausa) Apareciam por todos os lados" (p. 113). Supondo que os quatro habitantes desse abrigo são os últimos representantes da humanidade, o fim do mundo se dá por seguro, como se fosse evidente. Nem os ratos ou as pulgas podem sobreviver sob o risco de a humanidade ressurgir a partir de qualquer forma de vida: 
Clov: (Angustiado, se coçando) Acho que é uma pulga!

Hamm: Uma pulga! Ainda há pulgas?

Clov: (Se coçando) A não ser que seja um piolho.

Hamm: (Muito perturbado) Mas a humanidade poderia se reconstituir a partir dela! Pegue-a, pelo amor de Deus!

Clov: Vou buscar o pó.

(Sai)

Hamm: Uma pulga! É apavorante! Que dia!

(Entra Clov com o pulverizador)

Clov: Voltei com o inseticida.

Hamm: Que ela tenha o seu quinhão! (BECKETT, 2010, p. 74-75)

Fora do espaço cênico, é a morte para o personagem que não está no palco; e, no palco, o que se tem é a encenação da morte em vida. A angústia é ter de aguardar o fim. Os "personagens" de Beckett, se é que podem ser chamados assim, incapazes de se comunicar com o restante da humanidade, são portadores dos despojos da civilização burguesa, do otimismo da razão iluminista convertido em falácia. A morte é tão desejada como também pouco sentida. Nell, a mãe de Hamm, morre, e isso quase não repercute no desenvolvimento da peça.

A presença de três gerações em cena e de uma quarta, fora do abrigo (que servirá de elemento potencialmente transformador da situação), remonta à ideia de permanência histórica dos homens, apesar da catástrofe. Mas as relações familiares, reduto de felicidade para a burguesia emergente no século XVII, são agora marcadas pela agressividade e violência, uns com os outros. Essa violência se observa tanto na fala de Nagg para Hamm, como de Hamm para Clov, reiterando que essa é a funesta herança deixada a cada geração que segue. De Nagg para Hamm:

Nagg: Quando você era um menininho e tinha medo da noite, quem você chamava? Sua mãe? Não. Eu. Deixávamos você berrar. Até trancávamos a porta para poder dormir. (Pausa) Eu estava dormindo, feliz, como um rei, e você me acordava para escutá-lo. Não era indispensável, não precisava de verdade que eu o escutasse. Além disso, eu não o escutei mesmo. (Pausa) Espero que chegue o dia em que você realmente precise que eu escute você, e precise ouvir a minha voz, qualquer voz. (Pausa) Sim, espero viver até lá, para ouvir você me chamando, como quando era um menino, com medo, no meio da noite, e eu era sua única salvação. (BECKETT, 2010, p. 98-99)

Hamm, depois de questionar a Clov acerca da saúde de seus olhos e pernas, pragueja profetizando, com volúpia, um futuro com a mesma escuridão e imobilidade que lhe são próprias e amaldiçoando-o com uma solidão ainda mais acentuada que a sua: 
Hamm: [...] Um dia você ficará cego, como eu. Estará sentado num lugar qualquer, pequeno ponto perdido no nada, para sempre, no escuro, como eu. (Pausa) Um dia você dirá, estou cansado, vou me sentar, e sentará. Um dia você dirá, tenho fome, vou me levantar e conseguir o que comer. Mas você não se levantará. E você dirá, fiz mal em sentar, mas já que sentei, ficarei sentado mais um pouco, depois levanto e busco o que comer. [...] Estará rodeado pelo vazio do infinito e nem todos os mortos de todos os tempos, ainda que ressuscitassem, o preencheriam, e então você será como um pedregulho perdido na estepe. (Pausa) Sim, um dia você saberá como é, será como eu, só que não terá ninguém, porque você não terá se apiedado de ninguém e não haverá mais ninguém de quem ter pena. (BECKETT, 2010, p. 77-78)

No contexto da peça, sequer há mais natureza. A reificação do mundo está completa, não existe nada que não tenha sido criado por mãos humanas e por elas destruído. O cão é de pelúcia, feito por Clov para Hamm. Nada há ao alcance da visão; "zero, zero, zero" é o que Clov informa a Hamm depois de observar pela janela, com uma luneta, o que há fora do abrigo. O horizonte é cinza. Mas Clov ainda pode andar. Esse é um aspecto importante. Clov é tido como uma espécie de clown (o que seria reforçado pela própria grafia de seu nome). É o único personagem que pode mover-se. E o clown, do ponto de vista de sua própria constituição, é caracterizado por um tipo de representação pouco estruturada, instável, calcada na fragilidade, mas também potente. Para Adorno (2003, p. 289), "se a psicanálise explica o humor dos clowns como regressão a uma etapa ontogênica precoce, então a regressiva peça de Beckett desce até esse ponto".

Em função da imobilidade e da escuridão, da impotência da ação dramática, Hamm dedica-se à narração de uma história que ninguém tem interesse em ouvir. Mesmo a necessidade de Hamm de ter um ouvinte é apenas aparente, o que reitera que a peça não retrata de modo algum um diálogo, mas tão somente sua forma esvaziada:

Clov: Para que eu sirvo?

Hamm: Para me dar as deixas. (Pausa) Avancei bastante na minha história.

(Pausa) Está bem avançada a minha história. (Pausa) Pergunte até onde eu cheguei.

Clov: Ah, falando nisso, e a sua história?

Hamm: (Muito surpreso) Que história?

Clov: Aquela que você conta desde sempre.

Hamm: Ah, você quer dizer o meu romance?

Clov: Isso.

(Pausa)

Hamm: (Com raiva) Continue, criatura, continue mais um pouco.

Clov: Você deve estar bem adiantado, imagino. 
Hamm: (Com modéstia) Ah, nem tanto, nem tanto. (Suspira) Há aqueles dias em que a inspiração não vem. (Pausa) É preciso esperar por ela. (Pausa) Nunca forçar, não, forçar nunca, é fatal. (Pausa) Uma questão de técnica, entende? (Pausa. Com força) Eu disse que mesmo assim consegui avançar um pouco. Clov: (Com admiração) Não acredito! Apesar de tudo você conseguiu avançar! Hamm: (Modesto) Ah, nem tanto, nem tanto, você sabe, mas em todo caso, melhor que nada.

Clov: Melhor que nada! É assombroso. (BECKETT, 2010, p. 101-102)

A ironia entre o "nunca forçar"e o modo como Hamm força o diálogo - para que Clov lhe dê as deixas que ele busca para contar sua história evidenciam a dificuldade do diálogo.

O enredo do romance contado por Hamm pode referir-se à história da chegada de Clov (se parece muito) como o menino a que a narrativa se refere, como pode não ser. Não há qualquer informação que afirme a veracidade desse fato, ou mesmo a identificação de Clov com o menino descrito. Esse romance em que Hamm estaria trabalhando, a história que conta desde sempre, diferentemente de qualquer narrativa prenhe de sentido, expressa uma vida humilhada que se arrasta, e a postura arrogante do "herói" frente à catástrofe.

A narrativa é entrecortada pelos autoelogios de Hamm à sua própria performance e indicações precisas acerca da temperatura registrada no termômetro, da intensidade do sol no heliômetro, da força dos ventos no anemômetro e da umidade do ar no higrômetro que constituem o cenário da história. Nela, um homem "coberto de lama e lágrimas" chega às vésperas do Natal à casa de Hamm, em busca de pão para o filho que deixara adormecido em uma cidade distante.

Hamm: [...] Então, que maus ventos o trazem? Ele ergueu para mim o rosto escuro, coberto de lama e lágrimas. (Pausa. Tom normal) Assim está bom. (Tom de narrador) Não, não, não olhe pra mim, não olhe pra mim! Abaixou os olhos então, murmurando qualquer coisa, desculpas provavelmente. (Pausa) Estou muito ocupado, tempo de festas, você sabe como é, tantos preparativos. (Pausa. Com energia) Afinal, qual é o motivo dessa invasão? (Pausa) Naquele tempo fazia, me lembro, um sol esplêndido, os heliômetros marcavam cinquenta. O sol mergulhava no... na... entre os mortos. (Tom normal) Bonito isso. (Tom narrativo) Vamos, vamos, apresenta tua súplica, o tempo urge. (Tom normal) Ah, isso sim é que é português! Enfim. (Tom narrativo) Foi então que ele criou coragem. É o meu filho, disse. Ai ai ai, uma criança, que transtorno! Meu filho, ele disse, como se o sexo importasse. De onde veio? Ele me disse o nome do buraco. Umas boas dez horas, a cavalo. Não vá me dizer que o lugar ainda é habitado. Não, não, mais ninguém por lá, além dele e da criança, supondo que ela exista. Muito bem. Me informei 
sobre a situação em Kov, do outro lado do estreito. Nem um pecador. Muito bom. E quer que eu acredite que deixou seu filho lá, completamente só, e ainda por cima vivo? Ora! (Pausa) Naquele dia soprava, me lembro, um vento cortante, o anemômetro marcava cem. O vento arrancava os pinhos mortos e os varria... para longe. (Tom normal) Um pouco fraco isso. (Tom narrativo) Vamos logo, o que é que você quer? Ainda tenho que enfeitar o pinheiro. (Pausa) Em resumo, acabei compreendendo que ele queria pão para seu filho. Pão! Mais um pedinte! Pão? Olhe, eu não tenho pão, não me faz bem. Tudo bem. Cevada então? (Pausa. Tom normal) Assim está bom. (Tom narrativo) Cevada eu tenho, é verdade, nos meus silos. Mas pense bem. Eu dou um pouco de cevada, um quilo, um quilo e meio, você leva para o seu menino, faz, caso ele esteja vivo, uma panela de papa. (Nagg reage) Uma panela e meia, bem nutritiva. Tudo bem. O menino fica corado novamente, pode ser. E depois? (Pausa) Perdi a paciência. Use a cabeça, pense bem, você está no chão, não tem remédio! (Pausa) Naquele dia fazia, me lembro, um tempo excessivamente seco, o higrômetro marcava zero. Tempo excelente para meu reumatismo! (Pausa. Com violência) Mas qual é a sua esperança afinal? Que a terra renasça com a primavera? Que os peixes voltem aos mares e rios? Que haja maná do céu para imbecis como você? (Pausa) Aos poucos fui me acalmando, pelo menos o suficiente para perguntar-lhe quanto tempo levara para vir. Três dias inteiros. Em que estado tinha deixado a criança. Caída do sono. (Com violência) Sono! Que tipo de sono? (Pausa) Em resumo, propus que trabalhasse para mim. Ele tinha me comovido. E depois eu imaginava que não teria mais muito tempo. (Ri. Pausa) E então? (Pausa) Como é? (Pausa) Aqui, quem se cuidasse poderia morrer tranquilamente, uma confortável morte natural. (Pausa) E então? (Pausa) No fim, me perguntou se eu consentiria em recolher também a criança - caso ainda estivesse viva. (Pausa) Era o momento que eu esperava. (Pausa) Se eu consentiria em também recolher a criança? (Pausa) Ainda posso vê-lo, de joelhos, as mãos apoiadas no chão, me olhando fixamente com os olhos dementes, apesar da minha proposta. (Pausado normal) Chega por hoje. (Pausa) Essa história não dura muito mais. A não ser que crie outros personagens. (BECKETT, 2010, p. 95-96)

Essa narrativa, que surge como elemento que resume a história dos personagens, "fecha o enredo por dentro", não apontando para qualquer sentido exterior à cena. Se a antiga narrativa, como reduto da experiência, guarda um sentido precioso e mobilizador, essa apenas reitera o lugar e a função de cada um dos personagens em uma vida não vivida.

Para Adorno (2003), a inviabilidade do drama na era atômica consiste na impossibilidade de oferecer caracteres e ações humanas à crueldade do anonimato na destruição do mundo. A crise da experiência expressa por Walter Benjamin encontra seu resultado funesto. O esfacelamento do sentido metafísico, o único que avalizava a unidade da coerência estética de sentido, leva consigo o cânon formal da dramaturgia tradicional à falência. "O 
sentido estético unívoco, sobretudo sua subjetivação em uma intenção sólida, tangível, se sobrepõe precisamente àquela transcendente possessão de sentido cujo desmentido mesmo é o que constitui seu conteúdo" (ADORNO, 2003, p. 271). A construção do sem sentido tampouco deve deter-se frente às normas linguísticas, que surgem valorizadas mas esvaziadas de potência na narrativa de Hamm: "se essas, e suas combinações, tivessem um sentido racional, no drama se sintetizariam necessariamente naquela coerência de sentido do todo que o todo nega" (p. 271).

A noção de autonomia e potência do indivíduo, como centro do universo, ressurge em cena na implicância com que Hamm exige que seja posicionado exatamente no centro do palco após "uma volta ao mundo", cujas margens nada mais são que as paredes ocas da sala. Desse trecho pode-se depreender também a inexistência desse lugar central que Hamm busca e supõe como seu, já que ele se diz reiteradamente deslocado:

Clov: Ainda não demos a volta.

Hamm: Leve-me para o meu lugar. (Clov empurra a cadeira de volta ao centro) É aqui o meu lugar?

Clov: É, esse é o seu lugar.

Hamm: Estou bem no centro?

Clov: Vou medir.

Hamm: Mais ou menos, mais ou menos.

Clov: (Move minimamente a cadeira) Aí, pronto.

Hamm: Estou mais ou menos no centro?

Clov: Acho que sim.

Hamm: Acha que sim! Coloque-me bem no centro!

Clov: Vou buscar a trena.

Hamm: A olho nu! A olho nu! (Clov move minimamente a cadeira) Bem no centro!

Clov: Pronto.

(Pausa)

Hamm: Me sinto um pouco à esquerda demais. (Clov move minimamente $a$ cadeira. Pausa) Agora me sinto um pouco à direita demais. (Clov move minimamente a cadeira. Pausa) Me sinto um pouco pra frente demais. (Mesma coisa) Agora me sinto um pouco pra trás demais. (Mesma coisa) Não fique aí parado (Atrás da cadeira), você me dá arrepios. (BECKETT, 2010, p. 66- 67)

Mesmo o pensamento se resume a ideias que buscam a verdade por pura vaidade. $\mathrm{O}$ modo engenhoso como Clov propõe a resolução do "problema" de que, ansiando deixar o abrigo, Hamm saiba se ele realmente foi embora, ou se morreu na cozinha, atende ao simples desejo de Hamm de ter certeza do que de fato aconteceu, pois a diferença entre os acontecimentos "dá no mesmo": 
Hamm: Se você me deixar, como vou ficar sabendo?

Clov: (Vivamente) É só você apitar. Se eu não vier, é porque fui embora.

[...]

Hamm: Mas você poderia simplesmente estar morto na sua cozinha.

Clov: Daria no mesmo.

Hamm: É, mas como vou saber se você não está simplesmente morto em sua cozinha?

Clov: Bem, mais cedo ou mais tarde, eu vou feder.

Hamm: Você já fede. A casa toda fede a cadáver.

Clov: O universo todo.

Hamm: (Com raiva) Que se dane o universo! (Pausa) Pense em alguma coisa. Clov: Quê?

Hamm: Uma ideia, tenha uma ideia. (Pausa. Com raiva) Uma ideia brilhante. Clov: Ah, bom. (Começa a andar de lá pra cá, os olhos fixos no chão, as mãos juntas às costas. Para) Como doem minhas pernas, é incrível. Logo não poderei mais pensar.

[...]

Clov: Espere. (Ele se concentra. Não muito convencido) É... (Pausa. Mais convencido) É. (Levanta a cabeça) É isso. Eu ajusto o despertador.

(Pausa)

Hamm: Talvez eu não esteja num de meus dias mais brilhantes, mas...

Clov: Você apita. Eu não venho. O despertador toca. Fui embora. Ele não toca. Estou morto. (BECKETT, 2010, p. 89-91; grifo nosso)

As pernas, tal como o pensamento, permitem o deslocar-se. $\mathrm{O}$ esvaziamento dos sujeitos como sedes de reflexão e as consequências disso na capacidade dos homens de pensar e agir a fim de transformar sua situação, com vista à libertação de seu aprisionamento real (não apenas o seu, mas o de todos os homens) - encontram-se explícitas na fala final de Clov:

Clov: Às vezes digo a mim mesmo, Clov, você precisa aprender a sofrer melhor, se quiser que parem de te punir, algum dia. Às vezes me digo, Clov, você precisa melhorar, se quiser que te deixem partir, algum dia. Mas me sinto velho demais, e longe demais, para criar novos hábitos. Bom, isso nunca acabará, nunca vou partir. (Pausa) E então, um dia, de repente, acaba, muda, não entendo nada, morre, ou morro eu, também não entendo. Pergunto às palavras que sobraram: sono, despertar, noite, manhã. Elas não têm nada a dizer. (Pausa) Abro a porta da cela e vou. Estou tão curvado que só vejo meus pés, se abro os olhos, e entre minhas pernas, um punhado de poeira escura. Me digo que a terra está apagada, ainda que nunca a tenha visto acesa. (Pausa) É assim mesmo. (Pausa) Quando eu cair, chorarei de felicidade. (BECKETT, 2010, p. 127)

As resoluções individuais a que Clov tenta se aferrar em busca de uma saída à sua heteronomia apenas o reafirmam nesse lugar. A vida segue seu 
curso, e a morte é recebida com a alegria de quem encontra o que sempre viveu - morte em vida. As palavras não encontram sentido.

Ao supostamente visualizar uma criança fora do abrigo, Clov afirma que irá ao seu encontro. Mas a ação não se concretiza. O que se observa ao fim é que Hamm acredita que Clov o deixou, enquanto esse o observa. Mais uma vez se constata uma diferença fundamental entre o drama burguês e o "drama" presente em Fim de partida: "Em Beckett, a unidade paródica de lugar, tempo e ação age por episódios habilmente construídos e pensados pela catástrofe, que consiste no simples fato de ela [a ação teatral] não aparecer" (ADORNO, 2008, p. 236). Elemento fundamental do teatro, a ação surge como fragmento de ação, breves espasmos que não avançam, não oferecem saída.

Com Adorno (2008), entende-se como a ênfase de Samuel Beckett no estudo sobre a forma o torna privilegiado para uma análise da práxis social: "A obra de Beckett dá essa terrível resposta à arte que, pelo seu ponto de partida, a sua distância à práxis, e perante a ameaça mortal, se torna ideológica graças à inocência da simples forma e antes de todo conteúdo"'(p. 376). Ele não trata de produzir novos sentidos em uma ordem social autônoma, mas trata de desvelar, pelo estudo sistemático da forma, a história sem sentido da vitória do homem sobre a natureza: "Só quando o jogo percebe o próprio horror, como em Beckett, é que ele na arte participa possivelmente na reconciliação" (p. 482), a reconciliação possível entre natureza e espírito.

\section{CONSIDERAÇÕES FINAIS}

A incomunicabilidade que se observa na questão da crise da experiência, individualização e ruptura com o outro mostram seu resultado funesto em Fim de partida. A peça registra uma espécie de estágio terminal da palavra e da empatia, que ecoa no fim dos tempos que os personagens testemunham em face da morte da natureza e do outro.

A razão iluminista, universal e abstrata é duplamente facetada: garante a produção de condições materiais de existência para todos, mas, porque ancorada na desigualdade inerente ao modo de produção (que subsiste na necessária exploração de uns sobre os outros), nega o que promete. A (im)potência que resta à experiência e ao indivíduo reitera a manutenção de ordem social que se sobrepõe aos homens. Os conceitos de indivíduo (mesmo que pouco diferenciado) e de experiência (mesmo que convertida em vivência, incomunicável) mantêm alguma potência, na medida que resistem relações entre os homens, relações que necessariamente mobilizam o diverso. E que, portanto, podem gerar alguma ação/deslocamento. Se, em Sartre, o 
inferno são os outros, em Beckett, o outro é o que resta. Fora da cena, fora da relação, é a morte - apesar do que pouco resta a dizer.

Do ponto de vista coletivo, já não existem grandes ideais capazes de unificar as experiências humanas em torno de potentes significados. Do ponto de vista individual, a fragilidade e instabilidade observadas nas condições de existência se contrapõem à configuração de oportunidades reais de liberdade e decisão. Em uma sociedade massificada, pede-se "apenas" que o individual não perturbe a lei de mercado.

Enquanto a modernidade vive de promessas abstratas e dominação real, Fim de partida apresenta o que é possível depreender da concretude de uma existência que se encerra em si mesma, incapaz de algo universal, esgotada na pura autoposição. Tendo como horizonte uma abstração que não é capaz de chegar à experiência, e o homem ensimesmado, a aspiração do indivíduo à autonomia se torna inverossímil.

\section{THE (IM)POTENCY OF EXPERIENCE AND THE INDIVIDUAL IN ENDGAME}

ABSTRACT: This essay revisits the concepts of experience and the individual in Adorno, Horkheimer and Benjamin, in which they treat of the fragmentary and impotent character of the way they are presented in modernity. These considerations are our starting point for a reflection on Samuel Beckett's play, Endgame which, particularly for Adorno, is a realistic denouncing of the deteriorating conditions of the formation of the individual. It is by means of the form of parody in the drama that Beckett exposes the disruption of the possibilities of contact between people and between people, nature and the world. The (im)potency of experience and the individual is the price to be paid by humanity, which follows its course in progress at the cost of the death of everyone while still alive.

KEYwORDS: Experience. Individual. Frankfurt School. Modern theatre.

\section{LA (IM)POTENCIA DE LA EXPERIENCIA Y DEL INDIVIDUO EN LA OBRA FIN DE PARTIDA}

RESUMEN: Este ensayo retoma los conceptos de experiencia e individuo según Adorno, Horkheimer y Benjamin, en lo que los autores revelan sobre el carácter fragmentario e impotente con que esos conceptos se presentan en la modernidad. Se parten de tales consideraciones para reflexionar sobre la pieza Fin de Partida, de Samuel Beckett, la cual se muestra, de manera particular para Adorno, como una denuncia realista de las condiciones deterioradas de la formación del individuo. Es por medio de la forma de parodia del drama, que Beckett expone la dilaceración de las posibilidades de contacto entre los hombres y de estos con la naturaleza y el mundo. La (im)potencia 
de la experiencia y del individuo es el precio a pagar por la humanidad, quien sigue su curso en el progreso, a costa de la muerte en vida de todos.

Palabras Claves: Experiencia. Individuo. Escuela de Frankfurt. Teatro moderno.

\section{REFERÊNCIAS}

ADORNO, T. W. Intento de entender "Fin de partida". Notas sobre literatura. Obra completa 11. Madrid: Akal/Básica de Bolsillo, 2003. p. 270-310.

. Sobre la relación entre sociologia y psicología. Escritos sociológicos I. Obra completa 8. Madrid: Akal/Básica de Bolsillo, 2004. p. 39-78.

. Teoria estética. Trad. Arthur Morão. Lisboa: Edições 70, 2008. 408p.

\section{9.}

. Dialética negativa. Trad. Marco Antônio Casanova. Rio de Janeiro: Jorge Zahar, . Kierkegaard: construção do estético. Trad. Alvaro Valls. São Paulo: Unesp, 2010.

BECKETT, S. Fim de partida. Trad. Fábio de Souza Andrade. São Paulo: Cosac Naify, 2010. BENJAMIN, W. Experiência e pobreza. Documentos de cultura, documentos de barbárie. Trad. Celeste H. M. Ribeiro de Souza et al. São Paulo: Cultrix: USP, 1995. p. 195-198.

. O narrador. Considerações sobre a obra de Nikolai Leskov. Magia e técnica, arte e política: ensaios sobre literatura e história da cultura. Trad. Sérgio Paulo Rouanet. São Paulo: Brasiliense, 1996. p. 197-221.

CROCHÍK, J. L. A constituição do sujeito na contemporaneidade. Revista Inter-Ação, v. 35, n. 2, p. 387-403, jul./dez. 2010.

D'ANGELO, M. Arte, política e educação em Walter Benjamin. São Paulo: Edições Loyola, 2006.

DIDEROT, D. Discurso sobre a poesia dramática. São Paulo: Cosac Naify, 2005.

HORKHEIMER, M.; ADORNO, T. W. O indivíduo. Temas básicos de sociologia. São Paulo: Cultrix, 1973. p. 45-60.

. Dialética do esclarecimento. Trad. Guido Antônio de Almeida. Rio de Janeiro: Jorge Zahar, 1985.

ROSENFELD, A. O teatro épico. São Paulo: Buriti, 1965.

SZONDI, P. Teoria do drama moderno [1880-1950]. Trad. Luiz Sérgio Repa. São Paulo: Cosac Naify, 2001.

VASCONCELLOS, C. Figuras infernais no teatro de Samuel Beckett. Tese (Doutorado em Teoria Literária) - Faculdade de Filosofia, Letras e Ciências Humanas, Universidade de São Paulo, São Paulo, 2009. 
Yonara Dantas de Oliveira é doutoranda em Psicologia Escolar e do Desenvolvimento Humano pela USP; mestre em Psicologia Escolar e do Desenvolvimento Humano pela USP (2010) e graduada em Psicologia pela UFSJ (2006). Sua pesquisa acadêmica versa sobre formação, arte, teatro e individuação. Desenvolve pesquisas em avaliação de ensino no Programa de Pós-graduação Lato Sensu de Direito da GV (GVlaw).

Email: yonaradantas@yahoo.com.br 